\title{
Monitoring the threat of unintentional transgene flow into maize gene banks and breeding materials
}

\author{
Monica Mezzalama \\ Apdo. Postal 6-641 \\ 06600 Mexico, D.F., Mexico \\ Jonathan H. Crouch \\ 9 Davenham Avenue, Northwood \\ London, Middlesex, England \\ HA6 3HW, United Kingdom \\ Rodomiro Ortiz* \\ Martín Napanga 253, Apt. 101 \\ Miraflores, Lima 18, Perú \\ E-mail: r.ortiz@cgiar.org
}

Centro Internacional de Mejoramiento de Maíz y Trigo

Keywords: biosafety, genetic integrity, germplasm enhancement, GM-maize.

\begin{abstract}
Abbreviations: CGIAR: Consultative Group on International Agricultural Research CIMMYT: International Maize and Wheat Improvement Center

GE: genetically engineered

GM: genetically modified

PCR: polymerase chain reaction
\end{abstract}

The use of transgenic crops is steadily increasing around the world, led by soybean (based on total area) and maize (in terms of total number of countries). Transgenic maize is grown in at least 17 countries across four continents: Africa, America, Asia and Europe. The comprehensive global spread of transgenic maize has significant implications for organizations involved in germplasm conservation and genetic enhancement; particularly as some countries require a GMO-free declaration when receiving shipments of maize germplasm. This article describes the protocol used by the International Maize and Wheat Improvement Center (CIMMYT) for monitoring unintentional transgene flow in maize genebank and breeding plots. The protocol is based on polymerase chain reaction (PCR) markers for detecting specific recombinant DNA sequences in bulked samples collected from sentinel plots. To date, no unintentional transgene flow has been detected in CIMMYT fields of maize genebank accessions or breeding materials.

Maize is the most widely grown food crop globally with a harvest in 2007 of 785 million tonnes (Mt), substantially higher than both rice (652 Mt) and wheat (607 Mt) (FAO, 2009). The total area used for maize cropping in 2007 was about 158 million hectares (Mha), below that of wheat (217 Mha) but very similar to that of rice (157 Mha). Although the maize production statistics are dominated by USA, China and Brazil, maize is a significant crop (over 50,000 ha) in nearly 100 countries, as compared to less than 40 for wheat and less than 30 for rice (FAO, 2009).

The use of transgenic crops is steadily increasing around the world (James, 2008). Genetically modified (GM) maize is commercially grown in more countries than any other crop including South, Central and North America, Europe, Africa and Asia. Nearly one quarter of the global maize area is now planted with GM cultivars. The use of transgenic maize in recent years has been associated with significant increases in the rate that maize yields have increased in Argentina, South Africa and the USA (Figure $1)$.

The spread of transgenic crops has strong implications for organizations such as the International Maize and Wheat Improvement Center (CIMMYT, Mexico) that exchanges large quantities of maize seed with over 80 countries around the world for evaluation trials, breeding programs and genebank activities. Several countries that have traditionally requested improved germplasm or genebank accessions from CIMMYT now stipulate that all materials they receive must be declared free of genetically engineered (GE) traits. In addition, there is general public concern about the unintentional introgression of transgenes in to maize landraces in Mexico and across Latin America. CIMMYT is committed to taking all possible measures to ensure the integrity of the genetic resources and improved germplasm that it conserves and distributes for the global public good.

*Corresponding author 


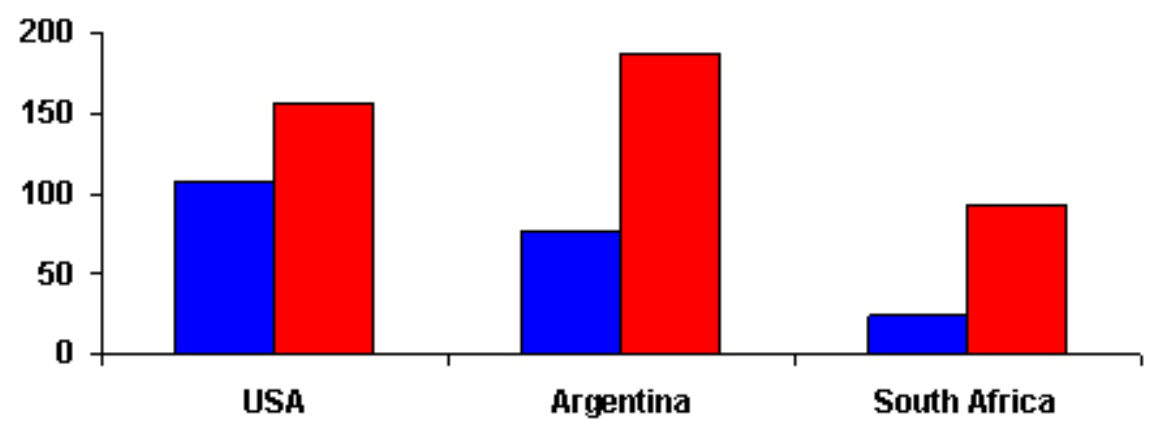

Pre-transgenic aPost-transgenic

Figure 1. Annual growth rates of maize grain yield $\left(\mathrm{kg} \mathrm{ha}^{-1}\right)$ in the United States of America, Argentina and South Africa before and after introducing transgenic maize in 1997, 1998 and 2000, respectively. The growth rates were calculated using data from FAOSTAT on 12 Feb. 2009 (FAO, 2009).

\section{Retaining the integrity of maize germplasm in the transgenic era}

The ways in which small-scale farmers in Mexico manage their maize germplasm and on describing how farmers' management practices affect gene flow, the genetic structure of maize landraces, their diversity and evolution are well known (Aguirre Gómez et al. 2000; Bellon and Risopoulos, 2001). Maize farmers in Mexico apply the same management to the modern cultivars as that given to their local landraces (Bellon and Brush, 1994; Bellon et al. 2003). In many instances, they favour mixing the two types -a process known as 'acriollamiento' or local adaptation. Hence, as pointed out by Bellon and Berthaud (2004), maize gene flow in Mexico should be seen both as biological and human phenomenon because some farmers deliberately mix seed from different sources with the express purpose of hybridizing them. Maize diversity in Mexico is therefore not static but changes constantly as a result of biological and social processes.

Given the high rate of out-crossing in maize, the extensive spread of GM maize cultivars has significant implications for maintaining the integrity of landraces in farmers' fields, conventional breeding material and cultivars during seed multiplication, and genetic resources during regeneration (Hoisington and Ortiz, 2008). Thus, genebank curators and maize breeders must take significant precautions during distribution of maize seed for research trials, breeding programs, genebank operations and germplasm exchange. Public concern was raised following the report of GE DNA sequences in Mexican maize landraces (Quist and Chapela, 2001). Although this report was subsequently counteracted (Ortiz-Garcia et al. 2005), the subject became a political issue in Mexico (the center of origin of maize) leading to a moratorium on GM maize in the March 2005 Mexican GM biosafety law, which established regulations for testing of all other GM crops for potential commercial release. After much scientific and political discussion, regulations were finally released in March 2009 facilitating the testing for potential commercial production of GM maize in limited areas in Mexico (see below for further details). Meanwhile, new reports of the transgenes in Mexican maize have highlighted critical factors associated with testing methodologies (Piñeyro-Nelson et al. 2009).

Immunoassays (ELISA) have been used to screen for the activity of recombinant proteins in farmers' maize seed stocks across Mexico (Dyer et al. 2009). Cry1Ab/Ac was detected in $3.1 \%$ of the samples tested while CP4/EPSPS was found in $1.8 \%$ of samples. It is postulated that seed diffusion (particularly grain imported from the United States of America) could account for the frequency and distribution of transgenes in west-central Mexico but that this is less likely to explain the occurrence in southeast Mexico. An illegal plantation of 70 ha of transgenic maize was discovered in the State of Chihuahua (northern Mexico) in September 2008. Although all the seed from this site was destroyed or confiscated by Mexico's Ministry of Agriculture (SAGARPA, 2008), there is no doubt that illicit cropping of GM maize in Latin America represents a major challenge to containing transgene flow to landraces and other maize-related genetic resources in the region. A special protocol for planting transgenic maize in Mexico was published in March 2009. It states that the Government of Mexico remains committed to in situ conservation of maize landraces and that the planting of GM maize will only be authorized if there is no conventionally bred maize cultivar available.

Since 2003 CIMMYT has developed and implemented a policy and procedure to minimize the likelihood of unintentional transgene flow during its germplasm regeneration and enhancement activities. CIMMYT also includes GM testing during the routine quarantine phase for all newly introduced germplasm and destroys any material which tests positive. Seed from all new introductions is quarantined in a location isolated from the genebank or breeders' seed working area until the analysis has been completed. CIMMYT out-sources all GM testing to an 


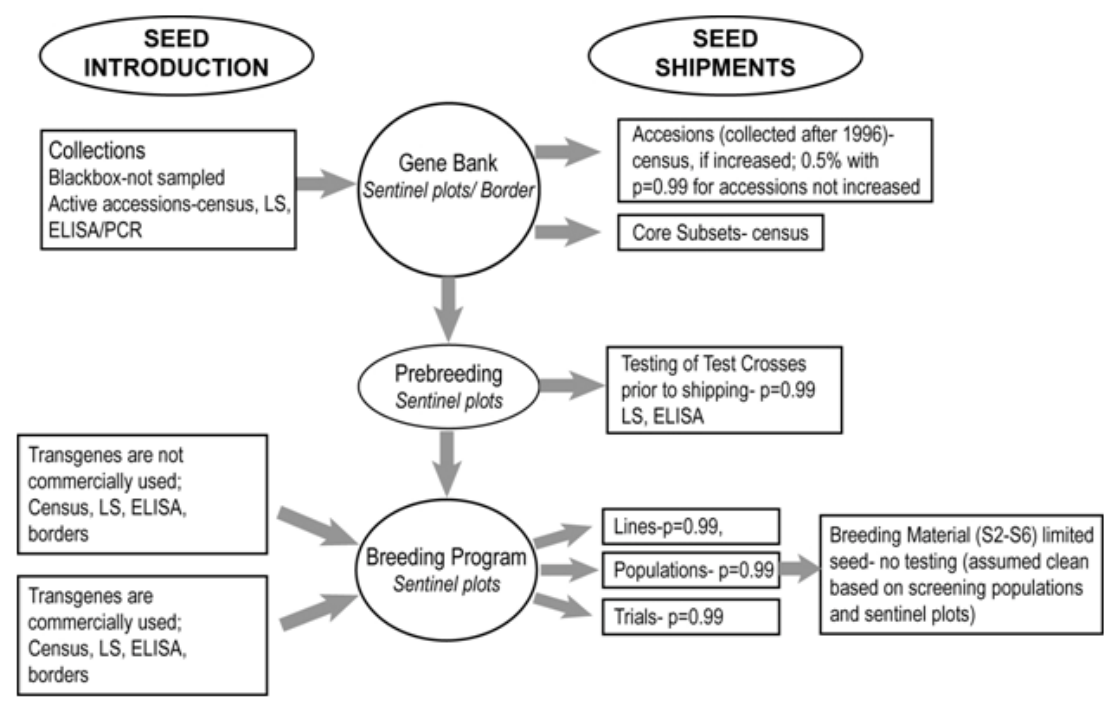

Figure 2. Schematic representation of CIMMYT seed movement, germplasm development and sampling protocols for detecting transgenic plants.

accredited service company in the USA, to ensure the unbiased credibility of its testing procedure. In this way, CIMMYT strives to minimize the possibility of inadvertently disseminating maize germplasm with harboring adventitious transgenes. CIMMYT will continue to facilitate the movement of germplasm by adopting ever more efficient, effective, and scientifically sound monitoring and testing standards. This article describes CIMMYT's current protocol for monitoring transgene flow in maize genebank and breeding plots.

\section{MATERIALS AND METHODS}

Maize plants are grown and single leaves subsequently harvested and sent to Genetic ID (Fairfield, Iowa, USA) to screen for the widely used, very strong constitutive promoter CaMV 35S (from Cauliflower Mosaic Virus), and nos (nopaline synthase from Agrobacterium tumefasciens) terminator. Should one of the two is detected, then the plant would be considered to be positive for the presence of a transgene. Genetic ID uses the state-of-the-art polymerase chain reaction (PCR) method, which allows direct analysis of the DNA and can detect GM content to $0.01 \%$. Transgene testing based on PCR are used worldwide to verify contracts and regulatory compliance. The PCR methods of Genetic ID are accredited to ISO 17025 standards.

\section{Protocol for monitoring transgene flow in maize germplasm}

The range of acceptable adventitious (or unintentional) presence of GE traits for commercial grain currently varies from as high as $5 \%$ for Japan to as low as $0.9 \%$ for the European Union (Le Buanec, 2003). The level of sensitivity of mandated detection methods also varies creating broader ranges in some countries. The Dorfman group testing method using a binomial distribution and considering both the dilution effect and the detection limit of the laboratory procedure has being advocated as the best approach (Hernández-Suárez et al. 2008). However, no system can provide $100 \%$ certainty that a seed stock does not contain any transgenes. For example, a sample size of 920 seeds or plants would be required to attain 99\% probability of detecting a transgene present at a rate of $0.5 \%$ or above (http://www.usda.gov/gipsa/biotech/samplingplan1.xls).

Census sampling (which means testing of each plant generated from each seed planted) is applied by CIMMYT for checking all seed introductions. Sentinel plots are used for monitoring all other materials planted on experiment stations. Sentinel plots are planted with maize lines with different maturity in order to cover the widest range of flowering times of maize crops surrounding CIMMYT experimental stations. Sentinel plots are planted facing the main wind streams and in proximity of neighbourhood maize crops. The seed from these sentinel plots is then tested in the same way as the census samples.

In order to develop an effective seed monitoring strategy that integrates the diverse range of germplasm products handled by genebanks and breeding programs, it is important to map seed movement associated with the different stages of germplasm development and exchange (Figure 2). In general, genetic diversity is greatest at the level of genebank accessions, which in turn are crossed to lines or pools from a breeding program for development of elite breeding populations and ultimately the widespread delivery of germplasm products in the form of lines, open pollinated (OPV) and hybrid cultivars. A sampling strategy should take into account the most probable sources of unintentional transgene flow, and the most effective and 
Table 1. Summary of protocols for detecting genetic engineered (GE) traits across distinct germplasm types.

\begin{tabular}{|c|c|c|c|}
\hline Germplasm & Protocol & Detection method & Response to positive tests \\
\hline $\begin{array}{l}\text { Black-box } \\
\text { collections }\end{array}$ & $\begin{array}{l}\text { Seed is stored and not } \\
\text { planted }\end{array}$ & no detection & \\
\hline $\begin{array}{l}\text { Accessions } \\
\text { collected prior to } \\
1996\end{array}$ & $\begin{array}{l}\text { Sentinel plots and borders } \\
\text { are harvested for sampling }\end{array}$ & $\begin{array}{l}\text { Polymerase chain } \\
\text { reaction }(\mathrm{PCR})\end{array}$ & $\begin{array}{l}\text { Harvested seed is tested to locate GE seed. } \\
\text { No seed is shipped until GE seed is } \\
\text { localized }\end{array}$ \\
\hline $\begin{array}{l}\text { Accessions } \\
\text { collected during } \\
\text { and after } 1996\end{array}$ & $\begin{array}{l}\text { Sentinel plots/borders and } \\
\text { census sampling }\end{array}$ & PCR & $\begin{array}{l}\text { Bulks testing positive will be disaggregated } \\
\text { to locate GE seed. Positive seed is } \\
\text { destroyed }\end{array}$ \\
\hline $\begin{array}{l}\text { Germplasm } \\
\text { enhancement (or } \\
\text { pre-breeding) }\end{array}$ & $\begin{array}{l}\text { Sentinel plots are } \\
\text { harvested for sampling, } \\
\text { census sampling of core } \\
\text { subsets }\end{array}$ & PCR & $\begin{array}{l}\text { Bulks testing positive will be disaggregated } \\
\text { to locate GE seed. Positive seed is } \\
\text { destroyed }\end{array}$ \\
\hline Introductions & $\begin{array}{l}\text { Sentinel plots/borders and } \\
\text { census sampling }\end{array}$ & PCR & $\begin{array}{l}\text { Bulks testing positive will be disaggregated } \\
\text { to locate GE seed. Positive seed is } \\
\text { destroyed and the collaborator is } \\
\text { confidentially informed }\end{array}$ \\
\hline $\begin{array}{l}\text { Breeding } \\
\text { populations }\end{array}$ & $\begin{array}{l}\text { Sentinel plots/borders and } \\
\text { census sampling of } \\
\text { populations (but not lines } \\
\text { derived from populations) } \\
\text { and advanced lines (> S6) }\end{array}$ & PCR & $\begin{array}{l}\text { Bulks testing positive will be disaggregated } \\
\text { to locate GE seed. Populations or lines will } \\
\text { be "cleaned" and GE seed destroyed }\end{array}$ \\
\hline Hybrid trials & Sentinel plots & PCR & $\begin{array}{l}\text { Seed produced will be sampled from all } \\
\text { entries }\end{array}$ \\
\hline
\end{tabular}

robust means of sampling the target material. The strategy must also take into consideration, the sampling and testing costs as well as the practicality of the monitoring process to ensure that any GM-free declaration is based on a protocol that can be stringent applied to all relevant germplasm.

\section{RESULTS AND DISCUSSION}

Maize genebanks need to continue collecting new diversity as well as working hard to maintain their current genetic resources without modifying their genetic structure. However, due to the out-breeding nature of the crop, curators of ex situ maize germplasm collections will still periodically need to repeat collection missions to replace diversity lost during the conservation and regeneration process. In addition, all new introductions received since 1996 (the date of the first approval for commercial production of GM maize) and all existing accessions regenerated after 1996 should be screened for the presence of unintentional transgenes based on testing of bulked leaf samples collected at the time of introduction or regeneration. Accessions with a seed origin that predates 1996 may be assumed to be free of commercially approved GE traits and probably should not be considered high priority for systematic testing. However, there remains an important unknown regarding unintentional gene flow of experimental GE traits that are particularly difficult to test for since public disclosure of gene sequence may not have been required in order to obtain government approval for field evaluation trials.

At CIMMYT, maize accessions are regenerated during both rainfed and irrigated cropping cycles, with the highest risk of unintentional transgene geneflow occurring during offstation plantings in the rainfed cycle, which is the traditional growing cycle for Mexican farmers. Regardless 


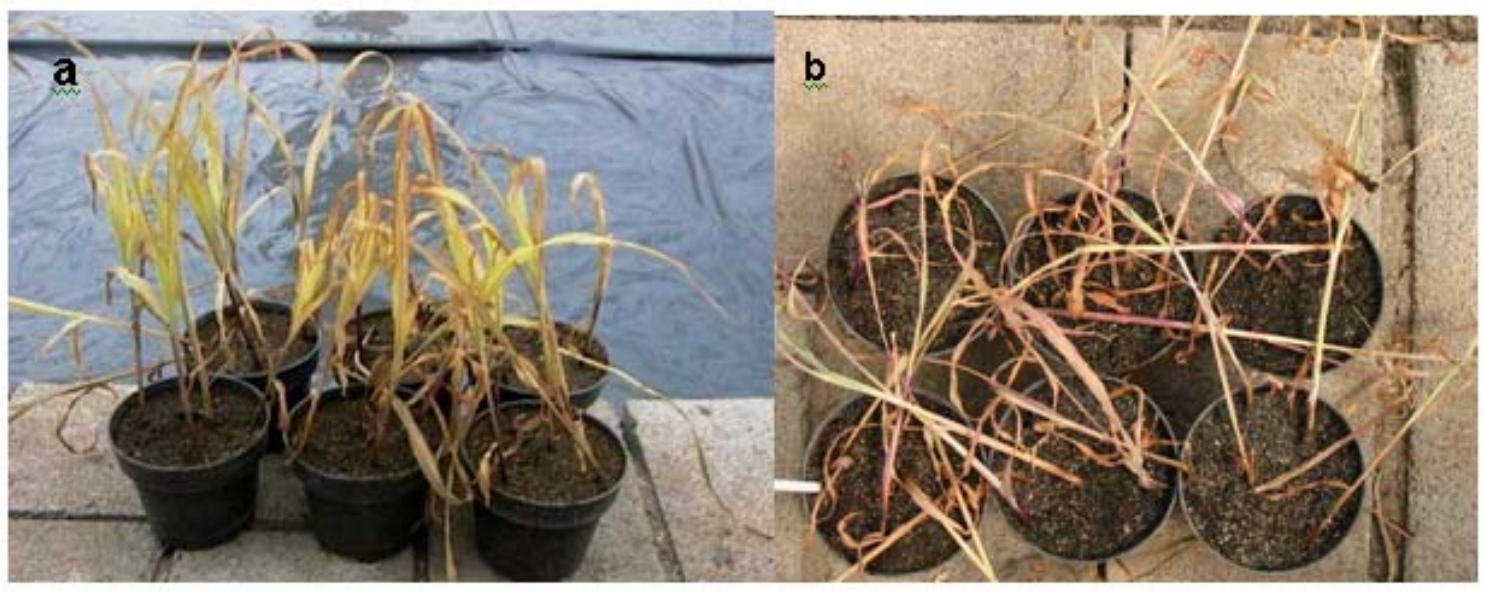

Figure 3. Transgene testing using herbicide resistance assays. a) Maize plants 10 days after being sprayed with Basta. b) Maize plants 19 days after being sprayed with Roundup.

of the cropping cycle, all regeneration plots should be surrounded by a $5 \mathrm{~m}$ deep border row, which can also be used as a sentinel plot. These border rows show include a blend of maize lines or hybrid cultivars representing a range of flowering dates that reflect the maturity groups of the accessions being regenerated. Sentinel plots are detasseled to increase the rate of cross pollination from maize plants outside the regeneration plot and from outside the experimental station, thereby improving the efficiency of detecting unintentional transgene flow. A similar process should be followed for all breeding trails and seed multiplication plots across the experimental station. Seeds collected from the sentinel plots should be germinated using standard seed germination test protocols to obtain leaf tissue from plantlets at the two-leaf stage. This will provide good DNA from the maximum proportion of seeds for analysis using standard polymerase chain reaction (PCR) marker tests for transgenes approved for commercial production. Should GE sequences be detected in the seed from sentinel plots, the genebank curator must test all accessions grown in the associated regeneration plot to identify any accessions that have also been exposed to unintentional transgene flow. If any accessions test positive, then the remnant seed of those accessions should be tested. If the remnant seed produces a negative test result, then the entire stock of newly regenerated seed should be destroyed and regeneration from the remnant seed repeated. Table 1 lists protocols, suggested detection method and response to positive tests for GE traits across distinct types of germplasm. In the past, phenotypic screening was also used by CIMMYT for herbicide tolerance and $B t$ insect resistance conveyed by transgenes approved for commercial production. Figure 3 shows previous results from transgene testing using herbicide resistance assays. No transgenes have been found to date in CIMMYT maize genebank accessions or breeding materials.

\section{Outlook}

Given the growing concern about unintentional transgene geneflow into genetic resources and conventionally bred germplasm, the Consultative Group on International Agricultural Research (CGIAR) is developing a policy for germplasm conservation operations and monitoring of new germplasm introductions (http://www.bioversityinternational.org/about_us/guiding_p rinciples/genebanks_and_transgenes.html). The overarching principles are based on ethics, transparency, accountability, risk analysis and quality control to address the threat of adventitious presence of transgenes in CGIAR ex situ collections and breeding plots. Crop-specific guidelines to maintain germplasm free from transgenes will need to be established. These guidelines will need to consider both maintaining germplasm free of transgenes and conserving transgenic crop germplasm. In addition, there is a need for information systems that monitor transgenic crop releases and central information resources on national regulations and latest best practice methods of transgene detection.

CIMMYT has participated in this process and will adhere to the CGIAR recommendations and guidelines as they emerge. The guidelines should also rely on best practices for preventing introgression of conventional genes because such an approach provides an appropriate basis for preventing introgression of transgenes. Of course, proactive steps must be taken to prevent the unintentional introgression of all exotic genes (including transgenes) because the maintenance of the genetic identity of genebank accessions and breeding materials should remain the overriding objective when managing plant genetic resources. 


\section{REFERENCES}

AGUIRRE GÓMEZ, José Alfonso; BELLON, Mauricio R. and SMALE, Melinda. A regional analysis of maize biological diversity in southeastern Guanajato, Mexico. Economic Botany, January 2000, vol. 54, no. 1, p. 60-72.

BELLON, Mauricio R. and BRUSH, Stephen B. Keepers of maize in Chiapas, Mexico. Economic Botany, April 1994, vol. 48, no. 2, p. 196-209.

BELLON, Mauricio R. and RISOPOULOS, Jean. Smallscale farmers expand the benefits of improved maize germplasm: a case study from Chiapas, Mexico. World Development, May 2001, vol. 29, no. 5, p. 799-811.

BELLON, Mauricio R.; BERTHAUD, Julien; SMALE, Melinda; AGUIRRE, José Alfonso; TABA, Suketoshi; ARAGÓN, Flavio; DÍAZ, Jaime and CASTRO, Humberto. Participatory landrace selection for on farm conservation: an example from the Central Valleys of Oaxaca, Mexico. Genetic Resources and Crop Evolution, June 2003, vol. 50, no. 4, p. 401-416.

BELLON, Mauricio R. and BERTHAUD, Julien. Transgenic maize and the evolution of landrace diversity in Mexico. The importance of farmers' behavior. Plant Physiology, 2004, vol. 134, no. 3, p. 883-888.

DYER, George A.; SERRATOS-HERNÁNDEZ, J. Antonio; PERALES, Hugo R.; GEPTS, Paul; PIÑEYRONELSON, Alma; CHÁVEZ, Angeles; SALINASARREORTUA, Noé; YÚNEZ-NAUD, Antonio; TAYLOR, J. Edward and ALVAREZ-BUYLLA, Elena R. Dispersal of transgenes through maize seed systems in Mexico. PLoS ONE, 2009, vol. 4, no. 5, e5734.

Food and Agriculture Organization of the United Nations (FAO). FAOSTATS [online]. Rome, Italy. 2009. Available from Internet: http://faostat.fao.org/site/339/default.aspx.

HERNÁNDEZ-SUÁREZ, Carlos M.; MONTESINOSLÓPEZ, Osval A.; MCLAREN, Graham and CROSSA, José. Probability models for detecting transgenic plants. Seed Science Research, June 2008, vol. 18, no. 1, p. 77-89.

HOISINGTON, David and ORTIZ, Rodomiro. Research and field monitoring on transgenic crops by the Centro Internacional de Mejoramiento de Maiz y Trigo (CIMMYT). Euphytica, December 2008,vol. 164, no. 3, p. 893-902.

JAMES, C. Global Status of Commercialized Biotech/GM Crops: 2008. Ithaca, N.Y.; International Service for the Acquisition of Agri-Biotech Applications, 2008.

LE BUANEC, B. Genetically modified varieties and the seed industry. Seed Testing International, April 2003, vol. 125, p. 12-15.
ORTIZ-GARCÍA, S.; EZCURRA, E.; SCHOEL, B.; ACEVEDO, F.; SOBERÓN, J. and SNOW, A.A. Absence of detectable transgenes in local landraces of maize in Oaxaca, Mexico (2003-2004). Proceedings of the National Academy of Sciences of the United States of America, August 2005, vol. 102, no. 35, p. 12338-12343.

PIÑEYRO-NELSON, A.; VAN HEERWAARDEN, J.; PERALES, H.R.; SERRATOS-HERNÁNDEZ, J.A.; RANGEL, A.; HUFFORD, M.B.; GEPTS, P.; GARAYARROYO, A.; RIVERA-BUSTAMANTE, $R$. and ALVAREZ-BUYLLA, E.R. Transgenes in Mexican maize: molecular evidence and methodological considerations for GMO detection in landrace populations. Molecular Ecology, February 2009, vol. 18, no. 4, p. 750-761.

QUIST, David and CHAPELA, Ignacio H. Transgenic DNA introgressed into traditional maize landraces in Oaxaca, Mexico. Nature, November 2001, vol. 414, no. 6863, p. 541-543.

SAGARPA. Asegura SENASICA cultivos de maíz genéticamente modificado. SAGARPA Bulletin, 2008, p. 183-208. 